\title{
Eklezjologia ludu Bożego w nurcie II Soboru Watykańskiego
}

Zainteresowanie życiem Kościoła, które w dzisiejszym świecie jest tak duże, że zdaje się przenikać nawet najgrubsze jego mury, dla samego Kościoła jest doskonałą okazją, aby objawić światu całe swoje piękno ${ }^{1}$, a przy tym przypomnieć zwłaszcza o tym, że jego tajemnica nie zamyka się jedynie w jego wymiarze widzialnym i zewnętrznym, a tym bardziej tylko ludzkim. Z misterium Kościoła, a więc z tym, poprzez co tajemnica Kościoła objawia się światu, ostatni w historii sobór - Watykański II - związał rozważania o ludzie Bożym nie tylko poprzez kolejność następujących po sobie rozdziałów, ale i poprzez nadanie rozdziałowi o ludzie Bożym wymiaru prawdziwie strategicznego ${ }^{2}$. Całe nauczanie o Kościele II Soboru Watykańskiego stanowi cenny i niezastąpiony skarb, do którego trzeba sięgać w każdym czasie. Posoborowa recepcja pojęcia ,lud Boży” bogata jest w ,,słowne fajerwerki”, jak dostrzega za Norbertem Lohfinkiem kard. Joseph Ratzinger, które jednak stopniowo wygasły zarówno dzięki niedającej się zmącić posłudze Kościoła, jak i zwłaszcza porządnej pracy teologicznej ${ }^{3}$. Jednym z najbardziej znaczących momentów pogłębionej refleksji eklezjologicznej był Nadzwyczajny Synod Biskupów zwołany przez papieża Jana Pawła II

1 Por. W. Henn, Church. The People of God, New York 2004, s. 149-152.

2 Por. F. G. Brambilla, Il Concilio Vaticano II, „bussola” per la Chiesa, [w:] Teologia del Vaticano II. Analisi storiche e rilievi ermenentici, a cura della Scuola di Teologia del Seminario di Bergamo, Cinisello Balsamo 2012, s. 21-22.

3 Por. J. Ratzinger, Kościót. Pielgrzymująca wspólnota wiary, tł. W. Szymona, Kraków 2005, s. 115. 
w celu uczczenia 20. rocznicy II Soboru Watykańskiego (24 października - 8 grudnia 1985 roku), który uznając «eklezjologię komunii» za centralną i podstawową ideę dokumentów Vaticanum $\mathrm{II}^{4}$, na nowo ukierunkował eklezjologiczne poszukiwania. Z perspektywy dziś nie tylko dwudziestu, ale już właściwie pięćdziesięciu lat od oficjalnego zatwierdzenia Lumen gentium [dalej: LG] rodzi się pytanie: czy rozumienie Kościoła jako ludu Bożego stanowi dalej ważną quaestio w eklezjologii, z którą łączy się także disputatio?, czy też jesteśmy dziś świadkami jej dalszego osłabienia albo nawet wygaśnięcia? ${ }^{5}$ Co dzieje się z kategorią „lud Boży” po soborze?6 A może lud Boży jest tylko jednym ze słów-haseł, które pozostały z eklezjologii Lumen gentium??

\section{Zarys historyczny}

Za znamienny moment w historii posługiwania się pojęciem „lud Boży" w odniesieniu do Kościoła uznaje się powszechnie reformę protestancką, która odrzucając kapłaństwo hierarchiczne, skoncentrowała się na powszechnym kapłaństwie wszystkich chrześcijan ${ }^{8}$. Marcello Semeraro, mówiąc o początkach teologii ludu Bożego, łączy je z całym procesem, jaki dokonał się w XIX wieku poprzez przewyższenie perspektywy indywidualistycznej i otwarcie na koncepcję wspólnotową Kościoła. Trzeba tu wspomnieć o takich autorach, jak: John Henry Newman (1801-1890), Friedrich Pilgram (18191890), Pierre Batiffol (1861-1929)9. Zwłaszcza dla ostatniego z nich, francuskiego księdza i historyka Kościoła, chrześcijanie są ludem

4 Por. Kongregacja Nauki Wiary, List do biskupów Kościoła katolickiego o niektórych aspektach Kościoła pojętego jako komunia Communionis notio, 1 [w:] W trosce o petnię wiary. Dokumenty Kongregacji Nauki Wiary 1966-1994, red. Z. Zimowski, J. Królikowski, Tarnów 1995.

5 Por. G. Mazzillo, Chiesa come „popolo di Dio” o Chiesa „comunione”?, [w:] Associazione Teologica Italiana, La Chiesa e il Vaticano II. Problemi di ermeneutica e recezione conciliare, a cura di M. Vergottini, Milano 2005, s. 47-48.

6 Pytanie to postawił już w 1985 roku sam przedstawiciel ,szkoły mediolańskiej” Giuseppe Colombo (1923-2005). Por. G. Colombo, Il „popolo di Dio” e il „mistero” della Chiesa nell'ecclesiologia postconciliare, „Teologia” 10 (1985), s. 103.

7 Por. J. Ratzinger, Kościót. Pielgrzymujaca..., dz. cyt., s. 114.

8 G. Frosini, La Chiesa..., dz. cyt., s. 25.

9 Por. M. Semeraro, Popolo di Dio. Una nozione ecclesiologica al Concilio e vent'anni dopo, „Rivista di Scienze Religiose” 2 (1988) 1, s. 35-36. 
Bożym w sensie bardziej biblijnym tego wyrażenia, ponieważ w Jezusie Chrystusie, synu Abrahama, stają się także oni jego potomkami i stanowią jeden lud ${ }^{10}$. W wieku XX teologia ludu Bożego zaczyna odnajdywać swoje miejsce w eklezjologii ${ }^{11}$. Pierwsze traktaty dedykowane ludowi Bożemu pojawiają się pod koniec lat 30. XX wieku, jako reakcja przeciw koncepcjom spirytualistyczym ujmującym Kościól jako społeczność niewidzialną, złożoną tylko ze świętych i wybranych. Prym wiedzie tu zwłaszcza opat Anscar Vonier (18751938) $)^{12}$, Ernst Käsemann (1906-1998) ${ }^{13}$ oraz dominikanin Mannes Dominikus Koster (1901-1981) ${ }^{14}$. Pogłębionemu studium myśli św. Pawła poświęcił się zwłaszcza Lucien Cerfaux (1883-1968), a owocem jego poszukiwań było uznanie idei ludu Bożego za fundamentalną dla Apostoła Narodów ${ }^{15}$.

Choć po publikacji przez papieża Piusa XII encykliki o Mistycznym Ciele Chrystusa (Mystici Corporis Christi) kategoria ludu Bożego zostanie częściowo przysłonięta ideą Mistycznego Ciała Chrystusa, to jednak coraz wyraźniejsza stanie się komplementarność obu kategorii ${ }^{16}$. Na potrzebę łączenia i wspólnego traktowania różnych obrazów i pojęć służących do wyrażenia tajemnicy Kościoła zwrócił uwage francuski teolog przedsoborowy Yves de Montcheuil (19001944) ${ }^{17}$. Niektórzy autorzy, dostrzegając ścisły związek kategorii eklezjologicznych, w obrazie Ciała Chrystusa widzieli właśnie ten wyją̧tkowy element, który odróżnia nowy od starego ludu ${ }^{18}$. Henri de Lubac (1896-1991), podkreślając oryginalność i doniosłość wyboru przez II Sobór Watykański kategorii ludu Bożego, widział także niezbędną rolę Pawłowego obrazu ciała ${ }^{19}$. Joseph Ratzinger jako początkujący teolog opowiedział się za niewystarczalnością pojęcia „lud Boży” dla wyrażenia istoty Kościoła nowotestamentalnego, gdyż Kościół tylko jako Ciało Chrystusa może być nazywany

10 Por. P. Battifol, L'Église naissante. L'idée de l'Église, ,Revue Biblique” 5 (1896), s. 369, 379-380.

11 Por. M. Semeraro, Popolo..., dz. cyt., s. 36.

12 Por. A. Vonier, The People of God, London 1937.

13 Por. E. Käsemann, Das wandernde Gottesvolk, Göttingen 1961.

14 Por. M. D. Koster, Ekklesiologie im Werden, Paderborn 1940.

15 Por. L. Cerfaux, La théologie de l'Église suivant saint Paul, Paris 1942.

16 Por. M. Semeraro, Popolo..., dz. cyt., s. 36-37.

17 Por. Y. De Montcheuil, Problemi della chiesa, Milano 1962, s. 22-23.

18 Por. M. Schmaus, Der Glaube der Kirche, t. 5/1, St. Ottilien 1982, s. 26.

19 Por. H. De Lubac, Paradosso e mistero della Chiesa, Milano 1979, s. 43. 
ludem Bożym i w tym też tkwi jego różnica w odniesieniu do ludu Izraela $^{20}$. Zdecydowanym orędownikiem pojęcia „lud Boży” jest francuski benedyktyn Ghislain Lafont (ur. 1928), który w odniesieniu do pojęcia communio podkreśla trudności w wymiarze liturgicznym (modlitwy w Mszale) i historycznym (inkulturacja), nie mówiąc już o duchowym²1.

\section{Lud Boży w konstytucji Lumen gentium}

Historyczne początki odrębnego rozdziału zatytułowanego najpierw De populo fideli, a następnie De populo Dei sięgają okresu pomiędzy zakończeniem pierwszej (8 grudnia $1962 \mathrm{roku}$ ) a rozpoczęciem drugiej (29 września 1963 roku) sesji II Soboru Watykańskiego ${ }^{22}$. Trwające ponad rok prace nad wykładnią rozdziału o ludzie Bożym oznaczają wielość wystąpień, dyskusji, głosów za i przeciw. Znamienny wkład w redakcję tego rozdziału wnieśli zwłaszcza: bp Joseph Gargitter (zabrał głos prawdopodobnie jako pierwszy), kard. Raúl Silva Henríquez, abp Lorenz Jäger, kard. Léon-Joseph Suenens (porządek rozdziałów ${ }^{23}$. Tekst ostateczny II rozdziału Lumen gentium został zatwierdzony 21 listopada 1964 roku $^{24}$.

Wyrażenie „lud Boży” występuje: 39 razy w Lumen gentium oraz 33 razy w innych tekstach Vaticanum II; 14 razy bez przymiotnika „Boży”; 3 razy jako „lud chrześcijański”; 3 razy jako „lud wierny”; 2 razy jako „lud Nowego Testamentu”; raz jako „nowy Izrael” i raz jako „lud kapłański”25. Dwa razy występuje też w numerze 9 Lumen gentium wyrażenie „lud mesjański”, którego gorliwym rzecznikiem był Yves Congar (1904-1995) ${ }^{26}$.

20 Por. S. Dianich, Ecclesiologia. Questioni di metodo e una proposta, Cinisello Balsamo 1993, s. 210.

21 Por. G. Lafont, Immaginare la chiesa cattolica. Linee e approfondimenti per un nuovo dire e un nuovo fare della comunità cristiana, Cinisello Balsamo 1998, s. 96.

22 Por. M. Semeraro, Popolo..., dz. cyt., s. 38.

23 Por. tamże, s. 39-40.

24 Na 1915 głosujących aż 1893 wyraziło swój ,,placet”. Por. M. Semeraro, Popolo..., dz. cyt., s. 40.

25 Zob. S. Pié-Ninot, Ecclesiologia. La sacramentalità della comunità cristiana, Brescia 2008, s. 160.

1026 Por. G. Frosini, La Chiesa..., dz. cyt., s. 93. 
II Sobór Watykański uprzywilejował pojęcie „lud Boży” pośród innych licznych obrazów i porównań zaczerpniętych z życia pasterskiego, rolniczego, a nawet $\mathrm{z}$ budownictwa. W ten sposób Vaticanum II dowartościował biblijne korzenie Kościoła ${ }^{27}$. Przedsoborowy rozwój eklezjologii Mistycznego Ciała Chrystusa i jej obecność w konstytucji Lumen gentium (nr 7) rodzi pytanie o relację tego obrazu do kategorii ludu Bożego. Podczas gdy Dominikus Koster w Ciele Chrystusa widział jedynie metaforę, a w ludzie Bożym prawdziwą i właściwą istotę Kościoła ${ }^{28}$, to dla innych autorów (Johanes Beumer, Michael Schmaus, Otto Semmelroth) wyrażenie „lud Boży” jest jednakowo metaforyczne jako Ciało Chrystusa. W całościowym ujęciu komentarzy dotycząych tego problemu możemy za Semeraro powiedzieć, że rysują się w tej kwestii trzy zasadnicze stanowiska: 1) tych, którzy opowiadają się za wzajemnym dopełnianiem się obydwu pojęć; 2) przyznających wyłączny prymat pojęciu „lud Boży”; 3) proponujących eklezjologię komunii, jako najbardziej właściwą, aby wyeliminować nieuniknioną polaryzację wynikającą z użycia zarówno pojęcia ludu Bożego, jak i pojęcia Ciała Chrystusa ${ }^{29}$.

Od samego początku rozdział o ludzie Bożym ma w Lumen gentium charakter strategiczny, gdyż wyraża się w nim powołanie wszystkich ludzi, a więc to, co jest wspólne tak hierarchii, zakonnikom, jak i świeckim, którym Vaticanum II poświęca kolejne rozdziały ${ }^{30}$. II Sobór Watykański, sięgając do znamiennych słów św. Cypriana „de unitate Patris et Filii et Spiritus Sancti plebs adunata” (LG 4), podkreśla, że „Kościól jest plebs, jest Kościołem ludu, nie dlatego, że się przeciwstawia Kościołowi élite, ruchów i grup, ale dlatego, że jest plebs adunata; jest ecclesia, jest świętym wezwaniem, jest ludem nie dlatego, że liczy

27 W rzeczywistości greckie wyrażenie laos Theou, choć występuje w Starym i Nowym Testamencie często, to jednak oznacza lud hebrajski. Tylko jeden raz w 1 P 2, 9-10 oznacza bezpośrednio chrześcijan. Sytuacja zmienia się radykalnie, jeśli pojęcie „lud Boży” uważa się domyślnie za obecne w terminie ekklesia, którym posługiwali się pierwsi chrześcijanie mówiący po grecku, na oznaczenie zgromadzenia ludzi zwołanych z inicjatywy Bożej. W takim sensie termin ekklesìa, w odniesieniu do wspólnoty chrześcijańskiej występuje aż 111 razy. Zob. E. Castellucci, La famiglia di Dio nel mondo. Manuale di ecclesiologia, Assisi 2008, s. 388-389. Por. E. Castellucci, La famiglia..., dz. cyt., s. 386; G. Philips, La Chiesa e il suo mistero, Milano 1975, s. 99.

29 Por. M. Semeraro, Popolo..., dz. cyt., s. 41-42.

30 Por. F. G. Brambilla, Il Concilio..., dz. cyt., s. 22. 
się głowy, ale dlatego, że jest gromadzony, wezwany, końcem i owocem duchowym wspólnego powołania" ${ }^{31}$. Wyrażenie natury Kościola poprzez pojęcie „ludu” uznane zostało przez niektórych teologów za prawdziwą „rewolucję kopernikańską, "32, gdyż Kościół nie wyraża się jedynie w hierarchii, ale ta jest w słuźbie wspólnoty i w nią jest doskonale włączona.

\section{Wybrane wypowiedzi posoborowego Magisterium}

Papież Paweł VI, ujmując w Credo Ludu Bożego naukę wiary o Kościele Chrystusowym, podkreśla także, że Kościól jest „Ludem Bożym pielgrzymującym tu na ziemi” ${ }^{33}$. O radości i żywotności ludu Bożego mówi papież Paweł VI w adhortacji apostolskiej o chrześcijańskiej radości Gaudete in Domino z 9 maja 1975 roku: „Kościól jako Lud Boży pielgrzymujący do przyszłego Królestwa, powinien ustawicznie tworzyć się i odnawiać w pokoleniach ludzi: to jest konieczny warunek jego płodności lub po prostu życia" ${ }^{34}$.

Już u progu pontyfikatu papież Jan Paweł II w swojej pierwszej encyklice przypomina: ,Jesli to Ciało Mistyczne Chrystusa jest - jak z kolei w związku z całą tradycją biblijną i patrystyczną uczy Sobór - Ludem Bożym, to znaczy, że każdy człowiek jakoś objęty jest w nim tym tchnieniem życia, które pochodzi od Chrystusa" ${ }^{35}$. O Kościele jako ludzie Bożym mówi papież Jan Paweł II w kontekście potrójnej misji Chrystusa ${ }^{36}$. Kościól jako lud Boży jest jednocześnie Mistycznym Ciałem Chrystusa: „Istotna dla całej wspólnoty Ludu Bożego

31 Tamże.

32 Por. G. Frosini, La Chiesa siete voi. Per una teologia conciliare del popolo di Dio, Fossano 2009, s. 29.

33 Paweł VI, Wyznanie wiary, 6a [Kraków 1968], s. 8.

34 Tenże, adh. apost. Gaudete in Domino, 6 [Poznań 1987], s. 27.

35 Jan Paweł II, enc. Redemptor hominis [dalej: RH], 18.

36 ,Teologia zawsze miała i nadal ma ogromne znaczenie dla tego, aby KościólLud Boży mógł twórczo i owocnie uczestniczyć w prorockim posłannictwie Chrystusa” (RH 19); ,,podstawowym zadaniem - a przede wszystkim widzialną łaską i źródłem nadprzyrodzonej mocy Kościoła jako Ludu Bożego - jest trwać i stale postępować w życiu eucharystycznym, w pobożności eucharystycznej, rozwijać się duchowo w klimacie Eucharystii” (RH 20); „Tenże Sobór, budując od samych podstaw obraz Kościoła-Ludu Bożego poprzez wskazanie na troiste posłannictwo samego Chrystusa, w którym uczestnicząc, 
i dla każdego jej członka jest nie tylko jakaś specyficzna «przynależność społeczna», ale istotne jest dla każdego i dla wszystkich szczególne "powołanie». Kościół bowiem jako Lud Boży jest równocześnie - wedle wspomnianej już nauki św. Pawła, ujętej tak wspaniale przez Piusa XII - «Ciałem Mistycznym Chrystusa»" (RH 21). Papież Jan Paweł II w konstytucji apostolskiej Sacrae disciplinae leges ogłoszonej z okazji wprowadzenia nowego kodeksu prawa kanonicznego z 25 stycznia 1983 roku, przypomina, że uwzględnia on także naukę o Kościele jako ludzie Bożym ${ }^{37}$.

Relacja końcowa II nadzwyczajnego zgromadzenia Synodu Biskupów z 1985 roku zredagowana przez kard. Godfrieda Danneelsa podkreśla, że „Sobór opisuje Kościół na różne sposoby jako lud Boży, ciało Chrystusa, oblubienicę Chrystusa, świątynię Ducha Świętego, rodzinę Bożą. [...], eklezjologia komunii (communio) jest ideą centralną i podstawową w dokumentach Soboru. [...] jest podstawą ładu (ordo), a przede wszystkim właściwego stosunku między jednością i różnorodnością w Kościele"38. Bezpośredni świadek Synodu, (obecnie) kard. Walter Kasper stwierdził w odniesieniu do pojęcia „lud Boży”, że niejednokrotnie było ono źle interpretowane, zwłaszcza poprzez wyrwanie z kontekstu historyczno-zbawczego Biblii lub

stajemy się właśnie Bożym Ludem, uwydatnił również ten rys chrześcijańskiego powołania, który wypada określić jako «królewski»” (RH 21).

„Dlatego Kodeks nie tylko ze względu na zawartość, lecz także w swoim powstawaniu ukazuje wpływ tego Soboru, w którego dokumentach Kościól, powszechny sakrament zbawienia (KK 9, 48) jest ukazany jako Lud Boży i jego konstytucja hierarchiczna jest przedstawiona jako mająca oparcie w Kolegium Biskupów razem z jego Głową. [...] Z elementów zaś, które wyrażają prawdziwą i własną naturę Kościoła, zwłaszcza te powinny być uwzględnione: doktryna, w której Kościół jest przedstawiony jako Lud Boży (KK 2), a władza hierarchiczna jako służba (KK 3), a ponadto doktryna, która ukazuje Kościól jako Wspólnotę i ustala wzajemne relacje, które powinny zachodzić między Kościołem partykularnym i powszechnym oraz między kolegialnością i prymatem; także doktryna, według której wszyscy członkowie Ludu Bożego, w sposób sobie właściwy, partycypują w potrójnym zadaniu Chrystusa, mianowicie kapłańskim, prorockim i królewskim, do której to doktryny dochodzi także wszystko, co dotyczy obowiązków i praw wiernych, a szczególnie osób świeckich; wreszcie troska Kościoła o ekumenizm" (Jan Paweł II, konst. apost. Sacrae disciplinae leges, „Osservatore Romano” 1 [1983], s. 14-15).

38 Dokument końcowy Nadzwyczajnego Synodu Biskupów z 1985 roku pt. Kościót kierowany przez Stowo Boże sprawuje Tajemnice Chrystusa dla zbawienia świata, Watykan 1985, s. 7-8. 
ujęcie w sensie naturalnym czy politycznym ${ }^{39}$. Zdaniem pólnocnoamerykańskiego teologa Josepha A. Komonchaka w oparciu o relację końcową synodu aż trudno uwierzyć, że „lud Boży” stał się tytułem całego rozdziału Lumen gentium, jednym z tematów nośnych całego soboru, że został wprowadzony właśnie jako element strukturalny wyrażający tajemnicę Kościoła pośród upływającego czasu pomiędzy wniebowstąpieniem a paruzją ${ }^{40}$.

W 1985 roku Międzynarodowa Komisja Teologiczna wydała opracowanie pt. Wybrane zagadnienia z eklezjologii (Themata selecta de ecclesiologia), gdzie choć mówi się wyraźnie, że „określenie «lud Boży» wyraża eklezjologię Soboru”41, to jednak ,z drugiej strony, wyrażenie «lud Boży» nie jest samo przez się oczywiste i jak każde inne wyrażenie teologiczne wymaga refleksji, pogłębienia i wyjaśnienia dla uniknięcia błędnych interpretacji”" ${ }^{42}$. Międzynarodowa Komisja Teologiczna zwraca więc uwagę, że: bogactwa znaczeniowego greckiego terminu laos nie jest w stanie oddać laciński termin populus; termin „lud” ma w Lumen gentium biblijne znaczenie i obcy jest mu sens czysto biologiczny, rasowy, kulturalny, polityczny czy ideologiczny, a dopelniacz „Boży” nadaje mu specyficznej i ostatecznej mocy; lud Boży bierze swój początek z Boga (,,z góry”) i z Nim jest nierozerwalnie związany, a poprzez odrodzenie w Jezusie Chrystusie i dzięki działaniu Ducha Świętego jest „nowym ludem Bożym” (LG 9); lud Boży odznacza się swoim istotnym odniesieniem do misterium Trójcy Świętej, a wobec świata objawia się jako „komunia wiary, nadziei i miłości” (LG 8), która ma swe źródło w Eucharystii (por. LG 3 i 7); istotny jest wymiar komunijny Kościoła i jego zaangażowanie ewangelizacyjne i społeczne ${ }^{43}$. Kongregacja Nauki Wiary w 1992 roku wydała list w calości poświęcony temu zagadnieniu ${ }^{44}$.

39 Por. W. Kasper, Il futuro della forza del concilio. Sinodo straordinario dei vescovi 1985, Brescia 1986, s. 61.

40 Por. G. Frosini, La Chiesa..., dz. cyt., s. 32-33.

${ }^{41}$ Wybrane zagadnienia z eklezjologii (1985), [w:] Od wiary do teologii. Dokumenty Międzynarodowej Komisji Teologicznej 1969-1996, red. J. Królikowski, Kraków 2000, s. 204. Por. G. Frosini, La Chiesa..., dz. cyt., s. 93.

42 Wybrane zagadnienia..., dz. cyt., s. 204.

43 Zob. tamże, s. 204-205.

44 Kongregacja Nauki Wiary, List do Biskupów Kościoła Katolickiego o niektórych aspektach Kościoła pojętego jako komunia Communionis notio, „L'Osservatore Romano” 10 (1992) (wyd. polskie) oraz w: W trosce o petnię 
Drugi rozdział encykliki Redemptoris Mater, który nosi tytuł: Bogurodzica $w$ pośrodku pielgrzymujacego Kościoła, zawiera rozważania na temat: Kościót, lud Boży-zakorzeniony wśród wszystkich narodów ziemi ${ }^{45}$.

Papież Franciszek w swojej pierwszej adhortacji Evangelii gaudium po jasnym stwierdzeniu, że „bycie Kościołem oznacza bycie Ludem Bożym, zgodnie z wielkim planem miłości Ojca"46 , zachęca do odkrycia duchowej przyjemności bycia ludem Bożym. Prawda o byciu ludem wypływa z Pisma Świętego (por. 1 P 2, 10), i jest tak istotna, że bez niej nie sposób wyobrazić sobie życia chrześcijanina, gdyż Jezus Chrystus „,chce się nami posługiwać jako narzędziami, by za każdym razem jeszcze bardziej się zbliżyć do swojego umiłowanego ludu. Bierze nas z ludu i posyła nas do ludu, tak że nie można zrozumieć naszej tożsamości bez tej przynależności do niego" (EG 268). Otwarcie serca, bycie blisko życia ludzi nie jest dla chrześcijanina jedną z możliwych opcji, ale tym istotnym elementem jego tożsamości, który czyni go najbardziej podobnym do samego Jezusa. Wtedy, ,gdy to czynimy, życie zawsze się nam komplikuje, lecz przeżywamy głębokie, cudowne doświadczenie bycia ludem, doświadczenie przynależności do ludu” (EG 270).

\section{Recepcja południowoamerykańska}

O roli i misji Kościoła na kontynencie południowoamerykańskim w drugiej połowie XX wieku mówią najlepiej Konferencje Ogólne Episkopatu Latynoamerykańskiego ${ }^{47}$. W całościowym ujęciu należy

wiary. Dokumenty Kongregacji Nauki Wiary 1966-1994, red. Z. Zimowski, J. Królikowski, Tarnów 1995, s. 390-401.

45 Por. Jan Paweł II, enc. Redemptoris Mater, 25-28.

46 Franciszek, adh. apost. Evangelii gaudium [dalej: EG], 114.

47 Konferencje Ogólne Episkopatu Latynoamerykańskiego należy odróżnić od Latynoamrykańskiej Rady Biskupów (CELAM), założonej z inicjatywy Pierwszej Konferencji Ogólnej Episkopatu Latynoamerykańskiego w celu podtrzymywania kontaktów i wspólpracy pomiędzy episkopatami poszczególnych krajów latynoamerykańskich. Wśród zadań CELAM-u znajdują się także - na prośbę poszczególnych papieży - przygotowanie i publikacja dokumentów końcowych konferencji ogólnych. Dokumenty Konferencji Ogólnych Episkopatu Latynoamerykańskiego, choć są przygotowywane, to jednak w rzeczywistości nie są dokumentami CELAM-u, gdyż ten ma swoje konferencje zwyczajne i nadzwyczajne. Pierwsza Konferencja Ogólna Episkopatu Latynoamerykańskiego zwołana przez papieża Piusa XII listem apostolskim Ad Ecclesiam 
podkreślić, że ,zdaniem biskupów wydarzenia ostatnich dziesięcioleci w Ameryce Łacińskiej stworzyły dogodne warunki recepcji eklezjologii interpretującej Kościół jako lud Boży - rodzinę pielgrzymującą przez historię w kierunku ostatecznego spełnienia w Bogu. Przemiany zapoczątkowane od założenia CELAM-u, przez Sobór Watykański II i przeobrażenia zachodzące w życiu społecznym wytworzyły odpowiedni klimat do rozumienia Kościoła jako «ludu». Podobne podłoże, ułatwiające zrozumienie Kościoła jako rodziny biskupi latynoscy dostrzegają w religijności latynoskiej i jej przejawach, jak np. pielgrzymkach, w których prości chrześcijanie celebrują radość życia wiarą wyznawaną przez dużą liczbę braci. Dlatego można powiedzieć, że w Ameryce Łacińskiej istnieje naturalne zrozumienie Kościoła jako rodziny"48. Kościól - lud Boży to także lud święty ${ }^{49}$. Jednym z ważnych wymiarów prawdy o Kościele jako ludzie pielgrzymującym jest rozumienie tzw. „Kościoła popularnego” czy też „Kościoła rodzącego się z ludu”. Rodzą się w tym kontekście poważne wątpliwości.

Christi odbyła się w dniach od 25 lipca do 4 sierpnia 1955 roku w Rio de Janeiro w Brazylii. Druga Konferencja Ogólna Episkopatu Latynoamerykańskiego odbyła się w dniach od 25 sierpnia do 6 września 1968 roku Medellín w Kolumbii. Jej temat brzmiał: Obecność Kościola w aktualnych przemianach Ameryki Łacińskiej w świetle Soboru Watykańskiego II. Trzecia Konferencja Ogólna Episkopatu Latynoamerykańskiego odbyła się w dniach od 28 stycznia do 13 lutego 1979 roku w Puebla w Meksyku. Konferencję odbywającą się pod hasłem: Ewangelizacja Ameryki Łacińskiej teraz i w przyszłości rozpoczął papież Jan Paweł II. Dokument końcowy obejmuje: Przestanie do ludów Ameryki Łacińskiej oraz Konkluzje. Czwarta z Konferencji Ogólnych Episkopatu Latynoamerykańskiego zainaugurowana przez papieża Jana Pawła II odbyła się w dniach od 12 do 28 października 1992 roku w Santo Domingo w Republice Dominikańskiej. Jej owocem jest dokument pt. Nowa ewangelizacja, promocja czlowieka, kultura chrześijańska. ,Jezus Chrystus, wczoraj, dziś i na wieki (Hbr 13, 8)”. Piąta Konferencja Ogólna Episkopatu Latynoamerykańskiego obradowała w dniach od 13 do 31 maja 2007 roku w Aparecida do Norte w Brazylii pod hasłem: Uczniowie i misjonarze Jezusa Chrystusa - aby nasze narody $w$ Nim miaty życie.

48 A. Pietrzak, Opcja..., dz. cyt., s. 146. Por. G. Frosini, La Chiesa..., dz. cyt., s. $64-65$.

49 „Wprawdzie w tym świecie, jak podkreśla dokument końcowy z Puebla, nigdy nie zdoła żyć w pełni swoim powołaniem do świętości i pozostanie zarazem święty i grzeszny, niemniej lud Boży jest ludem świętym, ponieważ rodzi się z Boga poprzez chrzest. Kościół - lud Boży ukierunkowuje swoje życie na Boga jako lud uświęcony w szczególny sposób, kiedy zgromadzony oddaje Mu cześć i chwałę. W ten sposób staje się Jego żywą świątynią i mieszkaniem pośród ludzi” (A. Pietrzak, Opcja..., dz. cyt., s. 147). 
W pierwszej kolejności „pomijając fakt, że określenie jest dość niefortunne, jeśli przez «Kościół popularny» rozumie się Kościól, który dąży do wcielenia się w środowiska ludowe kontynentu, i przez to powstaje z odpowiedzi na wiarę w Chrystusa, wówczas unika się problemu podstawowego: negacji prawdy fundamentalnej, że Kościół rodzi się na pierwszym miejscu «od góry», z Ducha pobudzonego przez Jezusa, który gromadzi swój lud. Nie do przyjęcia jest jednak taka interpretacja, która umieszcza «Kościól popularny» jako różny od tzw. Kościoła oficjalnego czy instytucjonalnego, który okresla się często jako "wyalienowany». Z tym łączą się dwa problemy: tworzenie podziału i niepoprawna interpretacja funkcji hierarchii. Takie stanowiska mogą mieć inspirację ideologiczną"50. Ponadto, „w Ameryce Łacińskiej po Soborze Watykańskim II powstały dwa przeciwstawne stanowiska. Z jednej strony usytuowali się ludzie, którzy wierzą, że Kościół jest niezmienny, a z drugiej ci, którzy chcą żyć w procesie ciągłych przemian. Zdaniem biskupów są to dwie niepoprawne skrajności. Kościół wprawdzie ulega zmianom na przestrzeni dziejów, ale jedynie zewnętrznie, i w tym, co nieistotne. Dlatego też nie można mówić o «Kościele starym» i «Kościele nowym». W Kościele należy też odróżnić element Boży i ludzki. Jezus Chrystus jest Synem Bożym na zawsze, choć w swym aspekcie fizycznym zmieniał się. Podobnie jest z Kościołem, który już posiada pewne wartości i nie szuka wszystkiego. Wprawdzie żyje nadzieją osiągnięcia tego, czego jeszcze mu brak, ale jest też i świadkiem tego, co posiada. W tym kontekście biskupi zwracają też uwagę na niebezpieczeństwa związane z poglądem wyrażonym w często powtarzanym i popularnym zdaniu: el camino se hace al andar - wędrując określa się droge, które wskazuje, że konkretne uwarunkowania mają wpływ na sposób i kierunek pielgrzymowania człowieka. Zdanie to może być prawdziwe, jeśli odnosi się do konkretnych uwarunkowań i doświadczenia życiowej drogi jednostki. Zastosowanie jednak do ludu Bożego nie jest poprawne, gdyż droga Kościoła została już zapoczątkowana i przebyta przez Chrystusa, świętych, zmarlych, którzy bronili integralności wiary i wolności Kościoła, służyli ubogim, Indianom, niewolnikom oraz tym, którzy doszli do najwyższych kontemplacji”" ${ }^{51}$.

50 Tamże, s. 150. Por. G. Frosini, La Chiesa..., dz. cyt., s. 66.

51 A. Pietrzak, Opcja..., dz. cyt., s. 150-151. Por. G. Frosini, La Chiesa .., dz. cyt., s. 66. 
Ujmując bardziej szczegółowo charakterystykę ludu Bożego, „Dokumenty końcowe z Medellín, Puebla i Santo Domingo podkreślają aspekt prorocki i posłania ludu Bożego. Zdaniem biskupów ten wymiar jest szczególnie obecny w historii Kościoła Ameryki Łacińskiej ostatnich dziesięcioleci. Lud Boży poprzez chrzest został posłany w celu przyczynienia się do wzrostu królestwa w innych ludach. Lud ten, głosząc Ewangelię, rozróżnia znaki czasu i demaskuje różne formy zła, które utrudniają realizację życia indywidualnego i zbiorowego opartego na wspóluczestnictwie, braterstwie i podziale dóbr stworzonych przez Boga dla wszystkich. [...] Zdaniem biskupów latynoskich Kościól, lud Boży, odgrywa rolę służebną w świecie. Będąc powszechnym sakramentem zbawienia, służy budowaniu jedności pomiędzy sobą. Specyfika służby Kościoła w świecie polega na ewangelizacji, która stanowi oryginalny wkład w dzieje ludzkości. Kościół, ewangelizując, służy wszystkim ludziom bez wyjątku. Jednakże jego działalność powinna zawsze odznaczać się szczególnym upodobaniem do najbardziej ubogich i cierpiących. Zadania te stoją przed całym ludem Bożym, bez wyjątku”52. Ponadto „w Dokumentach końcowych odnaleźć można silną tendencję do ukazywania wspólnotowego wymiaru Kościoła - ludu Bożego. [...] model ten jest szczególnie widoczny w Dokumencie z Puebla. Występujące tam kategorie jedności (communio) i współuczestnictwa (participatio) należą do centralnych pojęć tegoż Dokumentu [...]. W Dokumencie końcowym z Santo Domingo można odnaleźć elementy eklezjologii communio, które określają Kościól jako wspólnotę braci i interpretują tę kategorię w proponowanej przez Jana Pawła II perspektywie nowej ewangelizacji i problemów społecznych Ameryki Lacińskiej”"53.

\section{Wkład Josepha Ratzingera}

U początku eklezjologicznych poszukiwań Josepha Ratzingera stoi jego profesor Gottlieb Söhngen (1892-1971), z inicjatywy którego Ratzingerowi ,przypadło w udziale zadanie przestudiowania nauki Augustyna o ludzie Bożym, który jego zdaniem najszerzej tę ideę

A. Pietrzak, Opcja..., dz. cyt., s. 151. Por. G. Frosini, La Chiesa..., dz. cyt., s. 67.

53 A. Pietrzak, Opcja..., dz. cyt., s. 153-154. Por. G. Frosini, La Chiesa..., dz. cyt., s. 65,68 . 
przedstawil" ${ }^{4}$. Wynik podjętych z wielkim zapałem badań okazał się jednak nieproporcjonalny do zaplanowanych rezultatów. Choć termin „lud Boży” występuje w Nowym Testamencie, to jednak nie oznacza on Kościoła (za wyją̧tkiem najprawdopodobniej dwóch przypadków), ale Izrael. W całościowym ujęciu, zaznacza Ratzinger, „w Nowym Testamencie lud Boży nie jest nazwą Kościoła, lecz może oznaczać nowy Izrael tylko w chrystologicznej interpretacji Starego Testamentu, a więc w następstwie jego chrystologicznego przeobrażenia. Zwyczajną nazwą Kościoła jest w Nowym Testamencie słowo Ecclesia, które w Starym Testamencie oznacza zgromadzenie ludu przez wołające słowo Boga. Słowo Ecclesia - «Kościół» stanowi nowotestamentalną odmianę i reinterpretację starotestamentalnego terminu «lud Boży». Używa się go, ponieważ w swej treści zawiera myśl, że dopiero nowe narodzenie w Chrystusie z nie-ludu czyni lud. Później ten konieczny chrystologiczny proces przeobrażenia Paweł ujął sumarycznie w pojęciu Ciała Chrystusa" ${ }^{55}$. Nie sposób tu nie zaznaczyć także, według Ratzingera, zdania specjalisty od Starego Testamentu Norberta Lohfinka, który ,wykazal, że także w Starym Testamencie termin «lud Boży» nie oznacza Izraela po prostu w jego empirycznej sytuacji. Z wyłącznie empirycznego punktu widzenia żaden lud nie jest «ludem Bożym». Ukazywanie Boga jako znamię swego pochodzenia albo socjologiczny znak rozpoznawczy mogłoby zawsze być nieznośną uzurpacją albo wręcz bluźnierstwem. Izrael jest nazywany «ludem Bożym» nie sam w sobie, lecz w jego odniesieniu do Boga, w akcie relacji i przekroczenia samego siebie, który dopiero coś czyni tym, czym nie jest ono samo w sobie. Dlatego logiczna jest nowotestamentalna kontynuacja, którą ten akt odniesienia konkretyzuje w tajemnicy Jezusa Chrystusa, który zwraca się do nas i włącza nas przez wiarę i sakrament w swą relację do Ojca" ${ }^{" 56}$. Pogłębiając eklezjologię Vaticanum II, pojęcie „lud Boży” należy ściśle złączyć z innym podstawowym pojęciem Kościoła, a mianowicie $z$ sakramentem.

W obrębie rozważań nad pojęciem ludu Bożego warto zwrócić uwagę, zdaniem Ratzingera, na owoce poszukiwań znanego bizantynisty

\footnotetext{
54 J. Ratzinger, Eklezjologia II Soboru Watykańskiego, [w:] Joseph Ratzinger. Opera omnia, t. 8: Kościót - znak wśród narodów. Pisma eklezjologiczne i ekumeniczne, cz. 1, Lublin 2013, s. 248.

55 Tamże, s. 249.

56 Tamże.
} 
Endre von Ivánki (1902-1974) $)^{57}$, który wychodząc od obecnej już u Euzebiusza z Cezarei próby historiozbawczego dowartościowania cesarstwa rzymskiego i włączenia go w zbawczy plan Boży (idea chrześcijan jako „trzeciego ludu”), przechodzi następnie do kolejnej wersji tej koncepcji w teologii bizantyjskiej, wyrażającej się w idei trzeciego Rzymu po upadku Konstantynopola ${ }^{58}$. W przykrym wydarzeniu rozłamu (raskot - rozłam) w Rosyjskim Kościele Prawosławnym, jaki nastąpił po nieuznaniu przez staroobrzędowców reformy liturgicznej patriarchy Nikona z lat 1652-1656, i opowiedzeniem się za prymatem ludowej religijności, ujawnia się najlepiej nowożytna historia ducha, jako ,zlepek” sfery politycznej i religijnej, tradycji biblijnej i nowych mitologii ${ }^{59}$. W kontekście nowożytnej historii ducha

57 Chodzi o publikację Rhomäerreich und Gottesvolk: das Glaubens-, Staats- und Volksbewusstsein der Byzantiner und seine Auswirkung auf die ostkirchlich-osteuropäische Geisteshaltung, Freiburg-München 1968. Por. J. Ratzinger, Eklezjologia II Soboru Watykańskiego..., dz. cyt., s. 251-252.

Por. J. Ratzinger, Eklezjologia II Soboru Watykańskiego..., dz. cyt., s. 252.

Prosty lud uznał reformy patriarchy Nikona za zerwanie ciągłości i zniszczenie przekazanej wiary. Dla starowierców gwarantem tożsamości Kościoła nie jest odtąd sakrament apostolskiej sukcesji, ale lud w swej stałości i nieomylności. Ten początkowo mało znaczący fakt i niemający wpływu na wielką historię staje się z czasem, a zwłaszcza w XIX wieku, zarzewiem brzemiennych w skutki inspiracji w myśli zachodniej Europy. Wraz z próbą odnowy narodowej tradycji Rosji na miarę ducha czasu od lat 40. XIX wieku przez przedstawicieli nurtu myśli politycznej określonej jako słowianofilstwo (najwybitniejsi przedstawiciele: Aleksiej Chomiakow, Iwan Kiriejewski, Konstantin i Iwan Aksakow, Jurij Samarin) nastąpił także powrót do idei starowierców, zwłaszcza ortodoksji nieodłącznie związanej ze świadomością ludu żyjącego we wspólnocie i stanowiącego Kościół ludowy. Wpływ słowianofilskiej orientacji usystematyzowanej zwłaszcza przez Aleksieja Chomiakowa (1804-1860) okazał się tak silny, że wpłynął na zachodnie pojęcie prawosławia. Pośród wiodących elementów szczególnej mocy nabrała opozycja ludu nie tylko wobec hierarchii, ale i Urzędu Nauczycielskiego, przez co prymatem cieszy się Kościół Ducha, Kościół pneumatyczny, Kościół miłości. Duży wpływ na rozumienie ludu jako tradentu Ducha w myśli słowianofilskiej odegrał niemiecki romantyzm Friedricha Schellinga (,duch ludu” - jako tradent duchowych wartości), a także wschodnioeuropejski romantyzm Johanna Herdera (pojęcie ludowości). To, jak bardzo pojęcie ludu jest dla Chomiakowa zlepkiem religijno-społeczno-politycznym, widać najlepiej w uznaniu rosyjskiej komunistycznej społeczności wioski („mir”) za społeczność autentycznie chrześcijańską. W podobny sposób jak myśl rosyjska również myśl Ameryki Łacińskiej została zarażona przez prądy ducha francuskiego [Jean-Jacques Rousseau (1712-1778); Claude Henri Saint-Simon (1760-1825)]. 
z jej istotnym pomieszaniem sfery politycznej i religijnej trzeba spojrzeć na takie posoborowe idee, jak: Kościół bazowy, „Kościół oddolny”, Kościół ludu, wspólnota jako tradent wszystkich akcji, tak religijnych, jak i społeczno-politycznych ${ }^{60}$.

O niezawężaniu koncepcji Kościoła jedynie do ludu Bożego, a w związku z tym, o trudnościach z tego faktu wynikających mówil kard. Joseph Ratzinger w wywiadzie udzielonym Vittorio Messoriemu ${ }^{61}$.

\section{Etapy w budowaniu eklezjologii ludu Bożego}

Zarys eklezjologii ludu Bożego minionego pólwiecza od II Soboru Watykańskiego ukazuje niełatwą jej drogę w posoborowej eklezjologii,

Nowe chrześcijaństwo, które zapewnia doskonałe zbawienie już na tym świecie, a które wyrosło z pojęcia „,nowego chrześcijaństwa” głoszonego przez Saint-Simona oraz koncepcji „religii cywilnej” Rousseau to Kościół, którego wymiar polityczny, społeczny i religijny oddaje najlepiej pojęcie „lud Boży”. Por. J. Ratzinger, Eklezjologia II Soboru Watykańskiego..., dz. cyt., s. 252-257. Por. tamże, s. 256.

${ }^{61}$, „...] przyjęcie koncepcji Kościoła jako «Ludu Bożego» niesie raczej ryzyko cofnięcia się, niż możliwość pójścia naprzód, bowiem kryje się w nim niebezpieczeństwo odrzucenia Nowego Testamentu, akceptacja tylko Starego. «Lud Boży» to w rzeczywistości, według Pisma Świętego - Izrael zjednoczony z Bogiem modlitwą i dochowaniem wierności. Definicja Kościoła ograniczona wyłącznie do tego określenia oznacza porzucenie koncepcji Kościoła zawartej w Nowym Testamencie, gdzie określenia «Lud Boży» używa się wyłącznie po to, by odwołując się do starotestamentowego elementu Kościoła, podkreślić Jego ciaggly charakter, a tym samym związek z Izraelem. Nowotestamentowa koncepcja Kościoła polega na przyjęciu idei «Ciała Chrystusowego». W takim ujęciu członkami Kościoła stajemy się nie przez przynależność typu socjologicznego, ale przez wszczepienie się w Ciało samego Pana za pomocą chrztu i Eucharystii. Natomiast w idei Kościoła jako «Ludu Bożego» kryje się sugestia eklezjologiczna, zwracająca nas w stronę Starego Testamentu, być może także sugestie polityczno-partyjne, kolektywistyczne. Kościól, który nie zachowuje bezpośredniego, żywego związku między tym, co stanowi jego składnik socjologiczny, a chrystologią, nie odpowiada nowotestamentowej katolickiej idei. Kościół bowiem nie wyczerpuje się w «kolektywie wierzących», ale jako "Ciało Chrystusa» jest czymś o wiele więcej niż sumą jego członków" (Raport o stanie wiary. Rozmowa Vittorio Messoriego przeprowadzona $w 1984$ roku z ks. kardynatem Josephem Ratzingerem - prefektem Kongregacji Nauki Wiary - obecnym papieżem Benedyktem XVI, Marki 1986, s. 42-43). 
którą znaczą różne etapy. Pierwszym z nich jest niewątpliwie entuzjastyczne przyjęcie, które wyraziło się w ogólnym zainteresowaniu pojęciem ludu Bożego i przybrało formę rozlicznych komentarzy ${ }^{62}$. Semmelroth w swoim znaczącym komentarzu do drugiego rozdziału Lumen gentium („Kościól, nowy lud Boży”) podkreśla dwa charakterystyczne elementy Kościoła jako ludu Bożego. Są nimi jedność, a właściwie istotowa równość (vera aequalitas) w obrębie ludu Bożego, oraz historyczność Kościoła, który jest ustanowiony przez Chrystusa jako lud zanurzony w historii ${ }^{63}$. Cały lud Boży uczestniczy w urzędzie prorockim, królewskim i kapłańskim Chrystusa, co nie stoi w sprzeczności z wyróżniającym się miejscem hierarchii ${ }^{64}$. Kościól jako lud Boży nie jest alternatywą do ludu Bożego w Starym Testamencie, ale jest nowym ludem Bożym wynikającym z Nowego Przymierza, w którym zrealizowały się stare obietnice. W istocie nie ma dwóch ludów, ale jeden nowy, który wszedł na miejsce starego ${ }^{65}$.

Po II Soborze Watykańskim eklezjologia ludu Bożego rozwinęła się wyraźnie w krajach Ameryki Południowej. Podczas gdy José Comblin (1923-2011) dostrzega, że temat Kościoła - communio nie może wykluczać tematu Kościół - lud Boży, a samo pojęcie „lud Boży” jest o wiele szersze ${ }^{66}$, inny eklezjolog brazylijski Cleto Caliman podkresła, że kategoria „lud Boży” lepiej wyraża dynamizm wspólnotowy i społeczny Kościoła włączonego w świat ${ }^{67}$. Zdaniem redemptorysty Marciana Vidala wybór w czasie Vaticanum II kategorii ludu Bożego podyktowany był w dużej mierze trudnościami wynikającymi z rozwoju teologii Mistycznego Ciała Chrystusa (triumfalizm i klerykalizm), w zestawieniu z którą temat ludu Bożego wydawał się bardziej biblijny i sprzyjający odnowie Kościoła, jego dialogu z całym światem $^{68}$. Gorliwy rzecznik eklezjologii II Soboru Watykańskiego, eklezjolog hiszpański Juan Antonio Estrada przypomina, że eklezjologia

62 Por. J. Ratzinger, Kościót. Pielgrzymujaca..., dz. cyt., s. 114.

63 Por. O. Semmelroth, La chiesa nuovo popolo di Dio, [w:] La chiesa del Vaticano II, a cura G. Baraúna, Firenze 1965, s. 446.

64 Por. tamże, s. 449.

65 Por. tamże, s. 451.

66 Por. J. Comblin, Il popolo di Dio [org. O povo de Deus, Paulus, São Paulo 2002], Troina 2007, s. 123n. J. Comblin w niektórych swych wnioskach jest też nazbyt surowy (wyeliminowanie pojęcia lud Boży po soborze jako zamiar powrotu do stanu eklezjologii przed soborem). Por. tamże, s. 130.

67 Por. G. Frosini, La Chiesa..., dz. cyt., s. 32.

2268 Por. M. Vidal, La chiesa popolo di Dio, Bologna 1978, s. 98. 
traktująca o misterium Kościoła nie może nie być zintegrowana z teologią drugiego rozdziału Lumen gentium, a to oznacza, że sama kategoria „lud Boży” nie może być ani zanegowana, ani ignorowana, ani lekceważona ${ }^{69}$.

Teologiczne zainteresowanie pojęciem ,lud Boży” osłabło znacznie, gdy wraz z czasem doszło do pomieszania biblijno-teologicznego znaczenia słowa „lud” z jego znaczeniem biologicznym, socjologicznym czy wręcz politycznym. W sposób jasny mówi o tym procesie Ratzinger, wskazując na ,dwie związane ze sobą tendencje: po pierwsze, redukcjonizm, który z soborowej eklezjologii pozostawia niemal tylko słowo «lud Boży», po drugie, modyfikowanie i poszerzanie jego znaczenia w sensie socjologizacji pojęcia Kościoła. «Ludowi» nadaje się znaczenie socjologiczno-polityczne. Jeśli Kościół można definiować, posługując się pojęciem «lud», to jego istotę i struktury prawne najlepiej jest ujmować w perspektywie socjologicznej i politycznej. W konsekwencji «lud Boży» staje się wehikułem antyhierarchicznej i antysakralnej idei Kościoła, a nawet kategorią rewolucyjną, odpowiednią do tworzenia nowego Kościoła"70. Niełatwym wyzwaniem dla eklezjologii ludu Bożego stało się przypisywanie coraz większego znaczenia kategoriom pragmatycznym i propagowanym przez nauki humanistyczne, na niekorzyść biblijnych i wyrażających bogactwo Tradycji Kościoła.

Kolejny ważny etap, jakim było wyrażenie przez specjalny synod w 1985 roku syntezy istotnych elementów eklezjologii Vaticanum II w jednym podstawowym terminie communio, przyczynił się do budowania eklezjologii komunijnej, pozostawiając jakby całkiem na uboczu obarczoną różnymi trudnościami i podejrzeniami eklezjologię ludu Bożego ${ }^{71}$.

69 Por. J. A. Estrada, Da chiesa mistero a popolo di Dio, Assisi 1991 (wyd. org. 1988), s. $7-8$.

70 J. Ratzinger, Eklezjologia II Soboru Watykańskiego..., dz. cyt., s. 251. Ponadto: ,W pierwszej fazie soboru razem $\mathrm{z}$ tematem kolegialności dominowało pojęcie «lud Boży», które szybko zaczęto rozumieć w ogólnym politycznym sensie słowa «lud», a w kontekście teologii wyzwolenia utożsamiano je z jego marksistowskim znaczeniem jako przeciwstawienie warstw panujących, a często nawet jako suwerenność ludu, którą należy odnosić również do Kościoła” (J. Ratzinger, Kościót..., dz. cyt., s. 114). Por. F. G. Brambilla, Il Concilio..., dz. cyt., s. 21.

71 „Ale następne lata pokazały, że wokół wszystkich pojęć, nawet tych najtrafniejszych, najgłębszych, mogą się gromadzić nieporozumienia. W miarę jak communio stawało się popularnym, chwytliwym hasłem, ulegało równocześnie 
Świadomość trudności i grożących niebezpieczeństw, choć z jednej strony zdaje się zniechęcać, to jednak z drugiej jest też pobudką do dalszych twórczych poszukiwań, w tym też w wymiarze eklezjologii ludu Bożego. Pośród licznych autorów warto wskazać tu cały szereg teologów włoskich, takich jak: Tullio Citrini ${ }^{72}$, Severino Dianich, Giuseppe Colombo, Giordano Frosini. W licznych swych publikacjach teolog z Pizy Dianich postuluje całościową i organiczną syntezę znaczenia wyrażenia „lud Boży”, a także opartej na nim eklezjologii ${ }^{73}$. Wychodząc z podstawowej prawdy, że wiodącą kategorią konstytucji Lumen gentium jest pojęcie „lud Boży”, teolog mediolański Colombo, podkreślając aktualny etap tej kategorii, jakim jest zapomnienie, które zresztą zdarza się nie po raz pierwszy w historii, postuluje jej odnowienie poprzez dowartościowanie wymiaru historycznego Kościoła ${ }^{74}$. Frosini w imię wierności soborowemu dziedzictwu w powszechnie przyjmowanej triadzie „misterium-komunia-misja” zabiega o dowartościowanie eklezjologii soborowej poprzez zamianę tej triady na „misterium-lud Boży-misja"75.

Pośród różnych autorów Giovanni Mazzillo reprezentuje opinię, według której eklezjologia communio nie tylko nie sprzeciwia się eklezjologii ludu Bożego, ale wręcz o nią prosi ${ }^{76}$. Biorąc pod uwagę, że Kościół jako lud Boży jest głęboko zakorzeniony w Trójjedynym Bogu, z którego czerpie swoją moc i siłę, i ku któremu nieustannie dąży w swym pielgrzymowaniu, w pierwszej kolejności należy dowartościować mesjańskość ludu Bożego, gdyż „poprzez mesjańskość

spłaszczeniu i zafałszowaniu. Tak samo jak w przypadku kategorii ludu Bożego, tak też i tutaj można było obserwować narastający proces horyzontalizacji i pomijania pojęcia Boga. Eklezjologię komunijną zaczęto coraz wyraźniej redukować do tematu relacji między Kościołami lokalnymi i Kościołem powszechnym, a tę z kolei coraz częściej sprowadzano do zagadnienia podziału kompetencji” (J. Ratzinger, Kościót..., dz. cyt., s. 119). W kontekście stających przed eklezjologią communio problemów Colombo powraca do kategorii ludu Bożego i pyta o to, czy nie należało raczej utrzymać wykładnię Vaticanum II o ludzie Bożym, starając się przy tym o ukazanie jej autentycznego znaczenia poprzez uporządkowanie błędnych jej interpretacji. Por. G. Colombo, Vaticano II e postconcilio: uno sguardo retrospettivo, „La Scuola Cattolica" 133 (2005), s. 3-18.

72 Por. S. Pié-Ninot, Ecclesiologia..., dz. cyt., s. 177.

73 Por. S. Dianich, Ecclesiologia. Questioni..., dz. cyt., s. 210.

74 Por. G. Colombo, Il „,popolo di Dio”..., dz. cyt., s. 98-110.

75 Por. G. Frosini, La Chiesa..., dz. cyt., s. 11.

2476 Por. G. Mazzillo, Chiesa come..., dz. cyt., s. 58. 
komunia może się harmonijnie komponować z teologią ludu Bożego, ponieważ Kościól jako wspólnota miłości nie jest w sprzeczności z wymiarem instytucjonalnym ani z tym bardziej historycznie i społecznie usytuowanym, złączonym z jego naturą ludu Bożego" "77.

\section{Walory i ograniczenia pojęcia „lud Boży”}

Kościół jest ludem Bożym lub bardziej precyzyjnie nowym ludem Bożym nie na zasadzie zastępstwa starego ludu Bożego, ale jako kontynuacja otrzymanych kiedyś od Boga obietnic, które zrealizowały się we wcieleniu Syna Bożego i zesłaniu Ducha Świętego.

Bogactwo eklezjologii ludu Bożego ma w sobie wiele wymiarów. Eklezjologia ta w pierwszej kolejności:

1) Uwydatnia jedność Kościoła, a więc to, co łączy wszystkich członków Kościoła, nie wykluczając przy tym tego, co ich odróżnia. Nawiązując do Congara można powiedzieć, że chodzi tu o jakość bycia uczniem Chrystusa. W szerszej perspektywie wydarzenie Kościoła rozciąga na całą historię zbawienia ${ }^{78}$. W sposób szczególny II rozdział Lumen gentium podkreśla prymat wspólnoty i komunii wiary ${ }^{79}$.

2) Mówi o katolickości Kościoła, o Kościele jako ludzie pomiędzy innymi narodami. Kościół, żyjąc w świecie, nie utożsamia się z nim. Będąc zaś spadkobiercą Izraela, nie kroczy już jak tamten po pustyni i w samotności, ale przemierza drogi ludzi, tak jak czynił to sam Pan Jezus. Pośród świata Kościół jest nasieniem jedności rodzaju ludzkiego, a ubogacony darami swojego Założyciela głosi i krzewi królestwo Chrystusa i Boga (LG 5), pośród różnych narodów i kultur. To zadanie ewangelizacyjne nosi nazwę inkulturacji, która winna dokonywać się na wzór przyjęcia przez Chrystusa natury ludzkiej ${ }^{80}$. Uniwersalność ludu Bożego wyraża się tak w jego wnętrzu, jak i na zewnątrz. Lud Boży jest ze swej natury ludem powszechnym, a więc i otwartym na wszystkie ludy ziemi, bez względu na to, jaką stanowią rasę lub wyznają religię ${ }^{81}$.

77 Tamże, s. 61-62.

78 Por. E. Castellucci, La famiglia..., dz. cyt., s. 393.

79 Por. E. R. Tura, La Chiesa „popolo di Dio”, „Credere Oggi” 5 (1985) nr 4, s. 46-47.

80 Por. M. Semeraro, Popolo..., dz. cyt., s. 47-48.

81 Por. C. Delpero, I Documenti del Concilio Vaticano II (1962-65), Città del Vaticano 2012, s. 22-25; G. Frosini, La Chiesa..., dz. cyt., s. 182. 
3) Wyraża dość jasno ciągłość pomiędzy Kościołem a Izraelem, a tym samym uwydatnia wielkość i niezwykłość planu Boga, który realizuje się w historii ludzkości. W nawiązaniu do Starego Przymierza na Synaju, Kościół - nowy Izrael wyrasta z Nowego Przymierza zawartego we krwi Chrystusa (1 Kor 11, 25). Siłą jednoczącą jest Duch Święty, który czyni Kościól ,wybranym plemieniem, królewskim kapłaństwem, narodem świętym, ludem [Bogu] na własność przeznaczonym [...] wy, którzyście byli nie-ludem, teraz zaś jesteście ludem Bożym, którzyście nie dostapili mitosierdzia, teraz zaś jako ci, którzy miłosierdzia doznali" (1 P 2, 9-10, wyróżnienia własne). W relacji do Izraela Kościół odnajduje także swój charakter mesjański, gdyż jako lud mesjański (LG 9) jest w świecie antycypacją i figurą odkupionej ludzkości, początkiem zbawienia, jakiego Bóg pragnie dla wszystkich ludzi ${ }^{82}$.

4) Oddaje doskonale historyczność Kościoła ${ }^{83}$. Kościół żyje w historii i poprzez nią zmierza wraz z całym światem do eschatologicznego wypełnienia. Niejako w jego DNA wpisany jest dynamizm i przemieszczanie się, bycie w drodze. Ten stan jeszcze bardziej uwydatnia obecną w Kościele zmienność, potrzebę reformy i nawrócenia $^{84}$. Z historycznością łączy się zwłaszcza podmiotowość, gdyż lud jest sam w sobie podmiotem aktywnym, świadomym siebie i swoich możliwości, które rozwija wraz z czasem. W tym wymiarze uwydatnia się także rola współuczestnictwa i współodpowiedzialności w życiu Kościoła, a także synodalności, która integruje, pogłębia i udoskonala kolegialność, oraz opinii publicznej, która pozostaje w ścisłym związku z najbardziej głośnym znakiem czasów współczesnych, jakim jest wolnośćs ${ }^{85}$.

5) Jest doskonałym lekarstwem na szczególnie bolesną chorobę czasów współczesnych, jaką jest indywidualizm. Zbawienie dokonuje się we wspólnocie i poprzez wspólnotę (por. LG 9). Tym, co stoi u początku zbawienia nie jest wola jednostki, ale wezwanie samego Boga, które odnosi się do całej ludzkości ${ }^{86}$.

82 Por. E. Castellucci, La famiglia..., dz. cyt., s. 396-401; G. Frosini, La Chiesa..., dz. cyt., s. 181-182; M. Semeraro, Popolo..., dz. cyt., s. 43-44.

83 Por. E. Castellucci, La famiglia..., dz. cyt., s. 390-392; E. R. Tura, La Chiesa..., dz. cyt., s. 47.

84 Por. G. Frosini, La Chiesa..., dz. cyt., s. 179-180.

85 Por. tamże, s. 180-181.

2686 Por. M. Semeraro, Popolo..., dz. cyt., s. 45-46. 
6) Kryje w sobie wysoką wartość antropologiczną. Kościół jest wspólnotą ludzi, która zakłada wolną odpowiedź każdego na Boże wezwanie. Kościół nie istnieje ani bez ludzi, ani ponad ludźmi. Chrześcijanin, stając się nowym czlowiekiem w Chrystusie, zostaje włączony także w Kościól, poprzez który rozlega się głos wzywający samego Boga. Bogactwo darów, jakie człowiek otrzymuje w Kościele, pozwala mu się otworzyć także na innych: communio sanctorum. Kościół jako lud święty potrzebuje zarazem ciągłego oczyszczania się (semper purificanda) ${ }^{87}$.

7) Wyraża wspólną godność wszystkich ochrzczonych. Wspólna godność to także istotna równość wszystkich ochrzczonych, nienaruszająca przy tym równie ważnych różnic, jakie wynikają z pełnionych funkcji. Różnice przynależą do Kościoła, ale można o nich mówić dopiero po wyjściu od podstawowej jedności. W tym wyraża się zwłaszcza eklezjologia komunii, dla której elementem podstawowym jest element sakramentalny (zwłaszcza chrzest), w odniesieniu do Kościoła rozumianego jako misterium ${ }^{88}$.

8) Pozwala wyrazić lepiej relacje pomiędzy Kościołami partykularnymi (lokalnymi) a Kościołem powszechnym. U ojców Kościoła, a także w liturgii termin populus wskazuje przeważnie na zgromadzenie lokalne, a zwłaszcza na zgromadzenie, które zbiera się, aby celebrować Eucharystię (synaksa), choć jest to zawsze jeden lud Boży zebrany z całej ziemi i ze wszystkich narodów. Patrząc zaś od strony Kościoła powszechnego, „Kościół Chrystusa jest prawdziwie obecny we wszystkich prawowitych miejscowych zgromadzeniach wiernych, które o ile trwają przy swoich pasterzach, nazywane są w Nowym Testamencie Kościołami. Są one bowiem na swoim miejscu nowym ludem powołanym przez Boga mocą i działaniem Ducha Świętego oraz wielką siłą przekonania (por. 1 Tes 1, 5)"\$9.

9) Uwypukla wymiar ekumeniczny, gdyż pojęcie ludu Bożego odznacza się swoją otwartością na dialog ekumeniczny zwłaszcza z protestantami, co jednak nie oznacza usunięcia lub pominięcia różnicy pomiędzy powszechnym kapłaństwem wiernych a kapłaństwem urzędowym, czyli hierarchicznym ${ }^{90}$.

87 Por. F. G. Brambilla, Il Concilio..., dz. cyt., s. 22-23; E. Castellucci, La famiglia..., dz. cyt., s. 393-394; M. Semeraro, Popolo..., dz. cyt., s. 46-47.

88 Por. G. Frosini, La Chiesa..., dz. cyt., s. 178-179.

89 Por. M. Semeraro, Popolo..., dz. cyt., s. 49; E. R. Tura, La Chiesa..., dz. cyt., s. 47.

90 Por. G. Frosini, La Chiesa..., dz. cyt., s. 182-183; M. Semeraro, Popolo..., dz. cyt., s. 49-50. 
10) Kładzie nacisk na mnogość - niezwykłą ,,fantazję” Ducha Świętego wpisaną w Kościół, która wyraża się na wiele sposobów: Kościolów, charyzmatów, stanów, osób, powołań itp. Kościól jest rzeczywistością złożoną, ale wielość i różność oznacza zarazem jedność, w tym także w wymiarze relacji pomiędzy hierarchią a świeckimi, którzy stanowią jeden lud Boży, prowadzony przez Ducha Świętego „do calej prawdy" (J 16, 13) $)^{91}$.

11) Pozwala lepiej wyrazić cały dynamizm eschatologicznego dążenia Kościoła ${ }^{92}$.

Zarówno samo pojęcie „lud Boży”, jak i budująca się na nim eklezjologia nie są wolne od trudności i ograniczeń:

1) Niebezpieczeństwo niejasności rodzące się już na poziomie języka. Podstawowa trudność we właściwym oddaniu znaczenia biblijnego terminu laos ${ }^{93}$ pogłębia się jeszcze bardziej z uwagi na zawarty w nim kierunek „od góry”, co w odniesieniu do wiary chrześcijańskiej oznacza pochodzenie Kościoła od Trójjedynego Boga (mówi o tym już św. Cyprian: ,de unitate Patris et Filii et Spiritus Sancti plebs adunata”) ${ }^{94}$.

2) Niebezpieczeństwo niejasności rodzące się ze współczesnego użycia terminu „lud”, z którym łączy się szczególny ładunek afektywny. Lud to te masy, które znajdują się pod przemożnym wpływem nielicznych władców i dążą do uniezależnienia. Lud wzrasta w świadomości przysługujących mu praw i staje w ich obronie. Teologiczne pojęcie ludu narażone jest na ryzyko jego upolitycznienia, a tym samym wciągnięcia w spiralę konfliktów i roszczeń ${ }^{95}$.

3) Uporczywa tendencja do utożsamiania ludu Bożego z laikatem. W istocie jest to tendencja odwrotna do zaplanowanej przez Vaticanum II. Zamiarem II Soboru Watykańskiego było ukazanie wspólnej podstawy, a więc tego, co łączy wszystkich wierzących ${ }^{96}$.

91 Por. G. Frosini, La Chiesa..., dz. cyt., s. 188

92 Por. E. Castellucci, La famiglia..., dz. cyt., s. 394; M. Semeraro, Popolo..., dz. cyt., s. 50; E. R. Tura, La Chiesa..., dz. cyt., s. 47.

93 Grecki termin laós jest odpowiednikiem hebrajskiego terminu מישנא (1. poj.), który oznacza Izraela jako lud Boży, w odróżnieniu do gr. éthne (l. mn.), który odpowiada hebr. gojim oznaczającego narody obce, pogan. Zob. G. Calabrese, Chiesa di Cristo chi sei? Riflessioni e schede di lavoro per educare i collaboratori e i laici in parrocchia al senso della Chiesa, Milano 2005, s. 163-164.

94 Por. P. Haffner, Mystery of the Church, Herefordshire 2007, s. 35-36; M. Semeraro, Popolo..., dz. cyt., s. 52.

95 Por. M. Semeraro, Popolo..., dz. cyt., s. 52.

96 Por. tamże, s. 52-53. 
4) Dostrzegalny jest brak ścisłości w użyciu pojęcia „lud Boży” w dokumentach soborowych. Ponadto, o ile pierwsze dwa rozdziały Lumen gentium pozostają ze sobą dobrze związane, o tyle trudniej jest o takim związku powiedzieć w odniesieniu do rozdziału trzeciego. Fakt ten potwierdza także dołączenie do rozdziału trzeciego zalącznika (nota explicativa praevia) ${ }^{97}$.

5) Brak energicznego wysiłku w thumaczeniu pojęć teologicznych na język prawny, co oznacza również posługiwanie się pojęciami mało znanymi, w tym także w obrębie samej eklezjologii ${ }^{9}$.

6) Potrzeba bardziej wyraźnej i czytelnej syntezy chrystologiczno-pneumatologicznej ${ }^{99}$.

7) Budowanie wieloaspektowej syntezy eklezjologicznej. Kościół jest nowym ludem Bożym, wychodząc z Ciała Chrystusa i pozostając w bliskim związku z kategorią sakramentu ${ }^{100}$.

8) Na niewystarczalność pojęcia „lud Boży”, zdaniem Jeana-Hervé Nicolasa, wskazują trzy następujące racje: a) nie rzuca wystarczającego światła na relację pomiędzy Chrystusem a Jego Kościołem; b) nie daje wystarczającej jasności co do hierarchicznej struktury Kościoła; c) również poza jego zasięgiem pozostaje relacja Kościoła do królestwa Bożego ${ }^{101}$.

\section{Wciąż aktualne postulaty}

Biorąc pod uwagę niezastąpione bogactwo eklezjologicznej kategorii „lud Boży”, a także związane z nią problemy, zwłaszcza te, które ujawnily się w procesie recepcji Vaticanum II, na szczególną uwage

97 Por. tamże, s. 53-54.

98 Por. tamże, s. 55.

99 Por. tamże.

100 U jej podstaw leży już soborowa wypowiedź: „ów lud mesjański, chociaż aktualnie nie obejmuje wszystkich ludzi, a niejednokrotnie okazuje się małą trzódką, jest przecież dla całego rodzaju ludzkiego najpotężniejszym zalążkiem jedności, nadziei i zbawienia. Ustanowiony przez Chrystusa dla komunii życia, miłości i prawdy, używany jest również przez Niego jako narzędzie zbawienia wszystkich i jest posłany do całego świata jako światłość świata i sól ziemi (por. Mt 5, 13-16)" (KK 9). Por. E. Castellucci, La famiglia..., dz. cyt., s. 395; M. Semeraro, Popolo..., dz. cyt., s. 55-56.

101 Por. J. H. Nicolas, Dalla Trinità alla Trinità, t. 2: La Chiesa e i Sacramenti, Città del Vaticano 1992, s. 33-34. 
zasługują podejmowane starania o jej odnowę poprzez powrót do samego jej źródła, którym jest II rozdział Lumen gentium. Ermanno Roberto Tura mówi o konieczności dalszego rozwijania zawartej w pojęciu „lud Boży” potrójnej dwubiegunowości dialektycznej. Kościól powinien jeszcze bardziej unikać skrajności i łączyć w sobie: wcielenie $\mathrm{z}$ eschatologią; to, co partykularne, z tym, co powszechne; wymiar boski z ludzkim ${ }^{102}$.

Wybitny znawca II Soboru Watykańskiego i jego dokumentów, któremu przypadał zaszczyt ukazywania prac soboru dziennikarzom zgromadzonym na konferencjach prasowych, Luigi Sartori, wskazuje na konieczność pogłębienia wymiaru ludzkiego i boskiego Kościoła jako ludu Bożego ${ }^{103}$. Kościół na przestrzeni wieków aż tak bardzo zdołał wejść w rzeczywistość ludzką, że po części uczynił ją własną, w tym także w zakresie organizacji i działania. Przyjmując postać zorganizowanej społeczności, na wzór antycznego Izraela, Kościól przestał niemalże odróżniać się od innych narodów. Model ludu Bożego, który przybrał formę ludu między innymi narodami, w wyniku zwłaszcza dążenia do autonomii poszczególnych części doprowadził także do utraty właściwego sensu katolickości Kościoła. O ile bliższe określenie „ludu”, czyli podmiotu Kościoła zawsze było ważne, o tyle dziś wydaje się, zauważa Sartori, że trzeba zwrócić uwagę na dwa dynamiczne czynniki, kształtujące podmiot, którym jest lud. Tymi czynnikami są kultura i historia, które ze swej strony powinny odznaczać się wielością modeli ${ }^{104}$. Kościól jako lud Boży, a więc jako przynależący do Boga i pełen Jego łaski, powinien objawiać się światu. Nie ma innej wyjątkowości Kościoła jak Jezus Chrystus, i tak jak On, cały Kościól jest wspólnotą tych, którzy potrafią się ogołocić i są ogołacani ,aż do śmierci - i to śmierci krzyżowej” (Flp 2, 6-8), aby mogła w pełni objawić się miłość Ojca pełna miłosierdzia i przebaczenia ${ }^{105}$. Dużym wyzwaniem jest dziś interpretacja dopełniacza „Boży”, tak aby Kościół - jak kiedyś Izrael - był świadomy swojego wybrania, a przy tym samego wybrania nie rozumial wedlug schematów starotestamentalnej sakralności, a więc w znaczeniu kultycznym (odseparowanie, zarezerwowanie, nietykalność). Dziś, „, epoce

102 Por. E. R. Tura, La Chiesa..., dz. cyt., s. 48-49.

103 Por. L. Sartori, La Chiesa popolo di Dio. Un tema conciliare da riprendere e approfondire, „Vita e Pensiero” 63 (1980) nr 4, s. 34-40.

104 Por. L. Sartori, La Chiesa..., dz. cyt., s. 36. 
«nowego» ludu Bożego, tzn. w epoce Kościoła, konieczne jest, aby to, co Boże ludu «Bożego», wyraziło się w komunikacji, jako uczestnictwo, jako rozlanie darów, jako pokój, jako obfitość Ducha Świętego. Oto zatem, aktualne zadanie, aby wyeliminować jakąkolwiek pozostałość sakralności w wyrażaniu się i w działaniu misyjnym Kościoła. Oto wypływające znaczenie soborowej definicji Kościoła jako znaku i narzędzia komunii, jako sakramentu intymnej jedności ludzi z Bogiem i między sobą" ${ }^{106}$. Przed ludem Bożym stoi to niezwykle ważne zadanie „reprezentowania” tego, co ludzkie, osób i ludów, ale w taki sposób, który jeszcze bardziej uwidoczni nie ideę zajmowania miejsca innych, ich zastępowania, ale owego działania „pro”, „na rzecz” innych, tak w momencie „,podnoszenia do góry, wznoszenia” eucharystycznego do Boga (anafora - z gr. ,podwyższenie - podniesienie się" - to modlitwa eucharystyczna albo kanon w czasie Mszy świętej), jak i w wydarzeniu łaski, która zstępuje od Boga ${ }^{107}$. Kościół jako lud Boży ma być jeszcze bardziej świadomy i wolny zarazem w przyjmowaniu odpowiedzialności, pełny życia.

Nowego wymiaru winna także nabrać potrójna godność mesjańska ludu Bożego: prorocka, kapłańska i królewska. Również i w tym wymiarze niebezpieczeństwem staje się popadnięcie w stary schemat ujęcia sakralnego ${ }^{108}$. Pierwsza z godności - godność prorocka w latach posoborowych została pogłębiona w pierwszej kolejności w aspekcie jej historyczności, a za mało w aspekcie uwydatniającym teologalność wiary, zarówno jako faktu, jak i zadania. Nowy lud Boży to chrześcijanie coraz bardziej świadomi własnej wiary i dojrzali w jej wyznawaniu, nie tylko zadowalający się posiadaniem specjalistów w tej materii, ale osobiście zdolni do przepajania kultury w procesie ewangelizacji narodów i grup społecznych ${ }^{109}$. Godność królewska, o której właściwe milczy II rozdział Lumen gentium, została związana w ostatnim czasie z tematem urzędów w Kościele, przez co sam Kościół stał się w pewnym sensie ,stacją usługową”. Istnieje zasadnicza różnica pomiędzy służeniem jako postawą a służbą jako dobrem. Dziś ludzkość jest bogata w dobra, ale uboga w dobroć. Zadaniem Kościoła jako ludu Bożego jest w tym względzie wpisywać w świat nowy styl życia oparty na „przykazaniu nowym” (por. J 13, 34), na postawie samego

\footnotetext{
106 Por. tamże, s. 37 (tłum. własne).

107 Por. tamże.

108 Por. tamże, s. 38.

109 Por. tamże.
} 
Jezusa, który stał się sługą (por. J 13, 1-15) ${ }^{110}$. W odniesieniu do godności kapłańskiej ludu Bożego jeszcze większego znaczenia winna nabrać nie sama rytualność i gesty symboliczne, ale na wzór samego Jezusa ofiara życia i osoby. Kościół jako lud Boży jeszcze bardziej powinien oprzeć się na właściwym mu ,podwójnym kapitale ludzkim, a więc na zdolności transcendowania historii, a zarazem zanurzenia w historię, aby składać go jako dar ofiarowany Bogu, owoc jego łaski, a więc możliwy do włączenia w ofiarę Chrystusa Kapłana, którą składa Ojcu" "111. Zadaniem Kościoła jest czcić i uwielbiać Boga za każdą manifestację łaski Chrystusa i chwały Boga, dzięki którym poprzez człowieka dokonuje się przekształcenie rzeczywistości ludzkiej i kosmicznej w perspektywie Królestwa ${ }^{112}$.

Kościół jest tajemnicą tak bogatą i niezgłębioną, że nie sposób jej ogarnąć jednym pojęciem lub kategorią. Również eklezjologia ludu Bożego nie może sobie rościć takiego prawa. Gdy jednak ucichły „słowne fajerwerki" (Lohfink, Ratzinger), a czas niesie nowe wyzwania, budowanie eklezjologii ludu Bożego i odkrywanie jej duchowego bogactwa jest wciąż aktualnym postulatem.

\footnotetext{
110 Por. tamże, s. 38-39.

111 Por. tamże, s. 39.

112 Por. tamże.
} 